\title{
HYPOGLYCEMIC ACTIVITY OF ETHYL ACETATE FRACTION COMBINATION OF MORINDA FRUIT AND CINNAMON BARK USING GLUCOSE-INDUCED IN MICE
}

\author{
IDA MUSFIROH ${ }^{1 *}$, NURFADILAH YUSUF ${ }^{2}$, MOELYONO MOEKTIWARDOYO ${ }^{3}$
}

${ }^{1}$ Department of Pharmaceutical Analysis and Medicinal Chemistry, Faculty of Pharmacy, Universitas Padjadjaran, ${ }^{2}$ Graduate Program of Faculty of Pharmacy, Universitas Padjadjaran, ${ }^{3}$ Department of Pharmaceutical Biology, Faculty of Pharmacy, Universitas Padjadjaran, Jl. Raya Bandung Sumedang KM. 21 Sumedang, 45363

*Email: ida.musfiroh@unpad.ac.id

Received: 25 Aug 2021, Revised and Accepted: 03 Oct 2021

\section{ABSTRACT}

Objective: Noni fruit (Morinda citrifolia L) and cinnamon bark (Cinnamomum burmannii) are plants that have the hypoglycemic effect on their ethyl acetate fraction in the single dose. This study was to determine the hypoglycemic activity of the combination of ethyl acetate fraction (FEM) and cinnamon bark (FEC) in glucose-induced mice, as well as the dose of the combination of FEM and FEC which could have a hypoglycemic effect.

Methods: The methods were including extraction using liquid-liquid extraction, identification by TLC, and assay of hypoglycemic activity in mice induced by oral glucose for a moment in the eight groups that were normal control, negative control, positive control, dose 1-5. The activity tests were performed at $30^{\text {th }}, 60^{\text {th }}, 90^{\text {th }}$ and $120^{\text {th }}$ of minutes.

Results: The research showed that the yield of FEM and FEC were 5.25\% and 8.05\%. Identification of compounds by TLC showed that the FEM and FEC were 4 and 3 spots. The results of a hypoglycemic test showed that the combination of FEM and FEC on glucose-induced mice showed a decreased effect of mice blood glucose levels better than a single dose of these fractions.

Conclusion: The hypoglycemic activity test at a combined dose of FEM $175 \mathrm{mg} / \mathrm{kg} \mathrm{BW}$ and FEC $150 \mathrm{mg} / \mathrm{Kg}$ BW have provided hypoglycemic activity better compared to other dose groups with a percentage decrease in average relative blood glucose at the $30^{\text {th }}, 60^{\text {th }}, 90^{\text {th }}, 120^{\text {th }}$ minute were $29.57 \%$, $44.94 \%, 43.40 \%$ and $40.55 \%$, respectively. Thus, the combination of the FEM and FEC in glucose-induced mice gave a hypoglycemic effect in mice.

Keywords: Hypoglycemic, Noni fruit, Cinnamon bark, Ethyl acetate fraction, Combination dose

(C) 2021 The Authors. Published by Innovare Academic Sciences Pvt Ltd. This is an open access article under theCC BYlicense (https://creativecommons.org/licenses/by/4.0/) DOI: https://dx.doi.org/10.22159/ijap.2021.v13s4.43849 Journal homepage: https://innovareacademics.in/journals/index.php/ijap

\section{INTRODUCTION}

Diabetes is a chronic disease that occurs because the pancreas does not produce enough insulin (a hormone that regulates blood sugar), or an ineffective condition of the body using the insulin it produces [1]. The prevalence of diabetes mellitus continues to increase from 2000 to 2019 and is one of the major health problems in the world. The International Diabetes Federation (IDF) (2019) states that approximately 463 million people live with diabetes worldwide [2].

Diabetes is usually treated pharmacologically based on the patient's condition [3]. The use of pharmacological therapy can provide unwanted side effects [4]. One example of side effects of oral antidiabetic metformin biguanide group can cause hypoglycemia, tremor (abnormalities in the nervous system), dizziness, vomiting, and nausea. oral antidiabetic sulfonylurea group i.e. glibenclamide can cause the same side effects as biguanide group but in this group the constipation effect can also occur. Thiazolidinediones have side effects of increasing fluid buildup in the body which will complicate the effect of heart work [5]. Thus, many studies on herbal compounds are used as antidiabetic drugs, including noni fruits and cinnamon bark that provide hypoglycemic effects with milder side effects [6]. Therefore, try alternative treatments that are more effective and remain safe where active pharmacological potentiality of metabolite content in herbal plants [7]. Based on research conducted by Sadino et al. (2018), ethyl acetate fraction of noni fruit with a dose of $1200 \mathrm{mg} / \mathrm{kg} \mathrm{WB}$ in rats can lower blood glucose levels of locally induced mice by decreasing blood glucose levels by $54.29 \%$. This dose was very high, so it might be less effective in use and in the development of dosage forms [8]. Meanwhile, cinnamon bark extract is known to reduce glucose levels at a dose of 200 and $300 \mathrm{mg} / \mathrm{kg} \mathrm{BW}$ in streptozotocin (SYZ) induced diabetic mice for $14 \mathrm{~d}$ [9].

In the current era, there has been a lot of research on the antidiabetic activity of noni fruit and cinnamon bark, but the antidiabetic activity of the combination of noni fruit and cinnamon bark has not been found in previous publications, as well as a single dose of extracts or fractions of noni fruit and cinnamon bark is still large to be formulated so that the amount to be consumed is also more. From these problems, we conducted research on the activity of a combination of ethyl acetate fractions of noni fruit and cinnamon bark as hypoglycemic. The purpose of this study is to determine the hypoglycemic activity of the combination of ethyl acetate fractions of noni fruit and cinnamon bark on glucose-induced mice as well as to determine the doses of a combination of noni fruit and cinnamon bark of ethyl acetate fractions that can provide hypoglycemic effects.

\section{MATERIALS AND METHODS}

\section{Plants material}

The noni fruit of Morinda citrifolia L. was collected from Bogor, West Java, Indonesia and the Cinnamon bark of Cinnamomum burmannii was collected from Lembang, West Java, Indonesia. The plant was identified at Plants Taxonomy Laboratory, Faculty of Mathematics and Natural Sciences, Universitas Padjadjaran.

\section{Preparation of extracts}

$4 \mathrm{~kg}$ of noni fruit and $3 \mathrm{~kg}$ of cinnamon were macerated in $70 \%$ ethanol at $24 \mathrm{~h}$ with 3 times repetitions. Separation of residue and filtrate were performed every $1 \times 24 \mathrm{~h}$ accompanied by the same solvent replacement to obtain the filtrate. The filtrate was collected and concentrated using a rotary evaporator at a temperature of 58 ${ }^{\circ} \mathrm{C}$ to obtain a viscous extract [10].

Fractionation of ethanol extract by liquid-liquid extraction (LLE)

The concentrated extract obtained was dissolved in water $(500 \mathrm{ml})$ and exhaustively extracted by consecutive liquid-liquid extraction with $\mathrm{n}$-hexane $(500 \mathrm{ml})$ and then ethyl acetate $(500 \mathrm{ml})$ using a separating funnel $(1000 \mathrm{ml})$. The n-hexane, ethyl acetate, and last remaining water fractions were evaporated to obtain fractions [11].

\section{Thin layer chromatography (TLC)}

The fractions of noni fruit and cinnamon bark were applied on TLC plate silica gel 60 F254 (Merck, Germany) and developed in mobile 
phase consisting of chloroform: ethyl acetate: methanol (7:2:1) for noni fruit and toluene: ethyl acetate (97:3) for cinnamon bark. TLC plate was visualized under UV light at wavelength $254 \mathrm{~nm}$ and 366 $\mathrm{nm}$ and sprayed using $\mathrm{AlCl}_{3}$ reagent [12].

\section{Animal}

Male mice (Swiss Webster strain) weighing about 20-30 g, mice used as many as 24 heads of 3 heads of each group based on Federer formula [13]. The mice were obtained from the Faculty of Medicine Universitas Padjadjaran. Mice first adapted to the condition of the cage for $1 \mathrm{w}$. During the adaptation period, mice were fed and water ad libitum. The research was carried out in the pharmacology laboratory, Universitas Padjadjaran and has received ethical approval by the Universitas Padjadjaran Research Ethics Committee number 520/UN6. KEP/EC/2021.

\section{Hypoglycemic activity}

Before testing hypoglycemic activity, mice were fasted for 18-24 h (ad libitum), then blood glucose levels were measured initially using a glucometer. The mice were grouped and given the treatment as follows:

Group 1 (NC): normal group (without induction)

Group 2 (C-): negative control (PGA 2\%)

Group 3 (C+): positive control (Glibenclamide $0.65 \mathrm{mg} / \mathrm{kg} \mathrm{BW}$ )

Group 4 (dose 1): single dose of FEM $175 \mathrm{mg} / \mathrm{kg} \mathrm{BW}$

Group 5 (dose 2): single dose of FEC $150 \mathrm{mg} / \mathrm{kg}$ BW

Group 6 (dose 3): combined dose of FEM $525 \mathrm{mg} / \mathrm{kg} \mathrm{BW}$ and FEC 50 $\mathrm{mg} / \mathrm{kg} \mathrm{BW}$

Group 7 (dose 4): combined dose of FEM $350 \mathrm{mg} / \mathrm{kg}$ BW and FEC $100 \mathrm{mg} / \mathrm{kg} \mathrm{BW}$
Group 8 (dose 5): combined dose of FEM $175 \mathrm{mg} / \mathrm{kg} \mathrm{BW}$ and FEC $150 \mathrm{mg} / \mathrm{kg} \mathrm{BW}$.

Each group then induce with anhydrate glucose with the dose of 3 $\mathrm{mg} / \mathrm{kg} \mathrm{BW}$ by oral route, except for the normal group. After 30,60 , 90 and $120 \mathrm{~min}$, blood glucose level were measured with Glucometer (Accu Check Active) [14].

\section{RESULTS}

The plants were taxonomically determined at Plants Taxonomy Laboratory, Faculty of Mathematics and Natural Sciences, Universitas Padjadjaran as Morinda citrifolia L. and Cinnamomum burmanni, collection number of $21 / \mathrm{HB} / 03 / 2021$ for Morinda citrifolia L. and 22/HB/03/2021 for Cinnamomum burmannii. The yield of ethanol extract noni fruit and ethanol extract cinnamon bark were $230.65 \mathrm{~g}(23.012 \%)$ and 288.72 (14.436\%), respectively.

The yield of noni fruit fractions obtained by LLE method for nhexane fraction, ethyl acetate fraction (FEM), and water fraction were $1.2822 \mathrm{~g}$ (2.56\%), $2.6297 \mathrm{~g}$ (5.25\%), and $18.8620 \mathrm{~g}$ $(37.72 \%)$ respectively. The yield of cinnamon bark fractions including for n-hexane, ethyl acetate (FEC), and water fraction were $0.9631 \mathrm{~g}(1.92 \%), 2.0136 \mathrm{~g}(8.05 \%)$, and $9.586 \mathrm{~g}(39.83 \%)$ respectively.

The fraction of noni fruit was spotted on TLC plate 60 F254 and developed in mobile phase consisting of chloroform: ethyl acetate: methanol (7:2:1) and toluene: ethyl acetate (97:3) for cinnamon bark. TLC plate was visualized under UV light at the wavelength 254 $\mathrm{nm}$ and $366 \mathrm{~nm}$ then detected by using $10 \% \mathrm{H}_{2} \mathrm{SO}_{4}$ spray reagent. Identification of compounds by TLC showed that there were 4 spots on FEM (Rf 1: 0.31; Rf 2: 0.36; Rf 3: 0.73; Rf 4: 0.8) fig. 1. and 3 spots on FEC (Rf 1: 0.15; Rf 2: 0.39; Rf 3: 0.61) fig. 1.

\section{Fraction of Noni fruit}

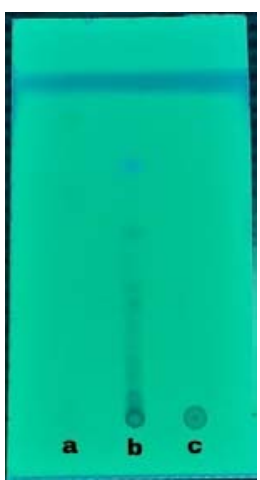

(1)

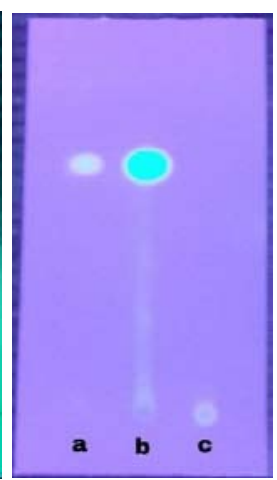

(2)

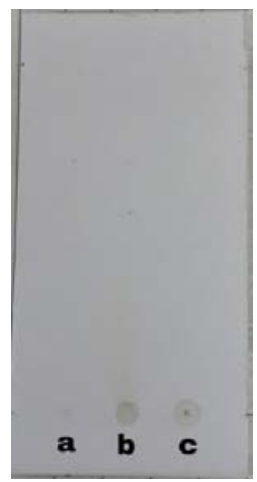

(3)

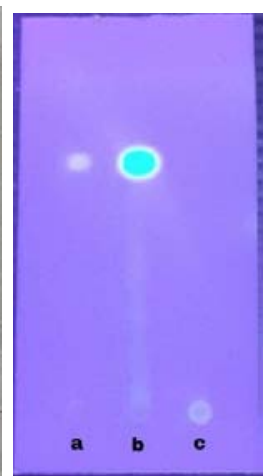

(4)

Fraction of cinnamon bark

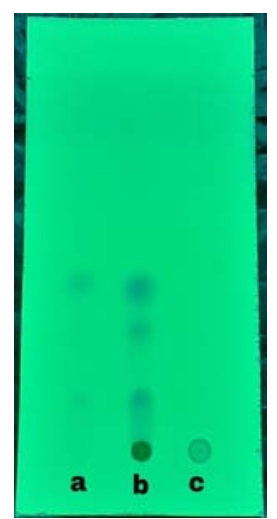

(1)

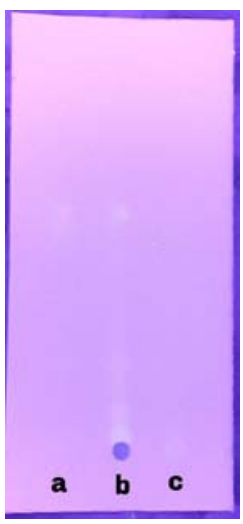

(2)

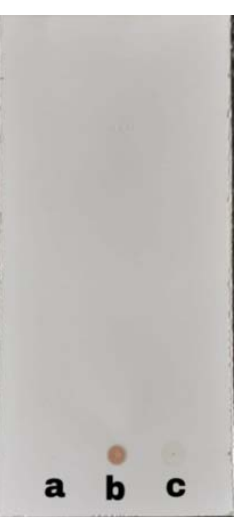

(3)

Fig. 1: TLC profile of fraction of noni fruit and cinnamon bark 
Information:
a. N-hexane fraction of noni fruit/Cinnamon bark
b. Ethyl acetate fraction of noni fruit/Cinnamon bark
c. Water fraction of noni fruit/Cinnamon bark
(1) Visualized under UV light at the wavelength UV $254 \mathrm{~nm}$
(2) Visualized under UV light at the wavelength $366 \mathrm{~nm}$
(3) Direct visualization

(4) Visualized under UV light at the wavelength $366 \mathrm{~nm}$ using $10 \%$ $\mathrm{H}_{2} \mathrm{SO}_{4}$ spray reagent.

Hypoglycemic activity of combination FEM and FEC was performed by glucose induction. The result of the average relative blood glucose level can be seen in table 1 and fig. 2 .

Based on the data of relative blood glucose levels that have been obtained, the percentage of the decrease in blood glucose levels relative to the negative control is calculated and the results can be seen in table 3 and fig. 3 .

Table 1: Average relative blood glucose level

\begin{tabular}{|c|c|c|c|c|c|c|c|c|}
\hline \multirow[t]{2}{*}{ Time (min) } & \multicolumn{8}{|c|}{ Average relative blood glucose level $(\mathrm{mg} / \mathrm{dl}) \pm \mathrm{SD}, \mathrm{n}=3$} \\
\hline & NC & $\mathbf{C +}$ & C- & Dose 1 & Dose 2 & Dose 3 & Dose 4 & Dose 5 \\
\hline 0 & $100 \pm 0.0$ & $100 \pm 0.0$ & $100 \pm 0.0$ & $100 \pm 0.0$ & $100 \pm 0.0$ & $100 \pm 0.0$ & $100 \pm 0.0$ & $100 \pm 0.0$ \\
\hline 30 & $106.7 \pm 2.2$ & $240.9 \pm 12.4$ & $362.9 \pm 57.5$ & $300.84 \pm 6.9$ & $315.1 \pm 72.9$ & $296.9 \pm 55.9$ & $291.6 \pm 19.0$ & $255.6 \pm 51.5$ \\
\hline 60 & $99.6 \pm 4.2$ & $170.0 \pm 31.4$ & $336.7 \pm 26.8$ & $261.5 \pm 13.0$ & $245.0 \pm 49.7$ & $242.7 \pm 60.9$ & $219.9 \pm 30.7$ & $185.4 \pm 54.2$ \\
\hline 90 & $116.9 \pm 5.5$ & $135.8 \pm 21.8$ & $275.3 \pm 52.4$ & $199.6 \pm 12.8$ & $209.4 \pm 37.4$ & $181.8 \pm 60.6$ & $192.9 \pm 20.2$ & $154.8 \pm 35.6$ \\
\hline 120 & $113.0 \pm 5.8$ & $100.2 \pm 9.6$ & $174.5 \pm 40.9$ & $142.4 \pm 15.6$ & $138.3 \pm 53.8$ & $136.3 \pm 35.5$ & $115.94 \pm 9.4$ & $103.7 \pm 25.7$ \\
\hline
\end{tabular}

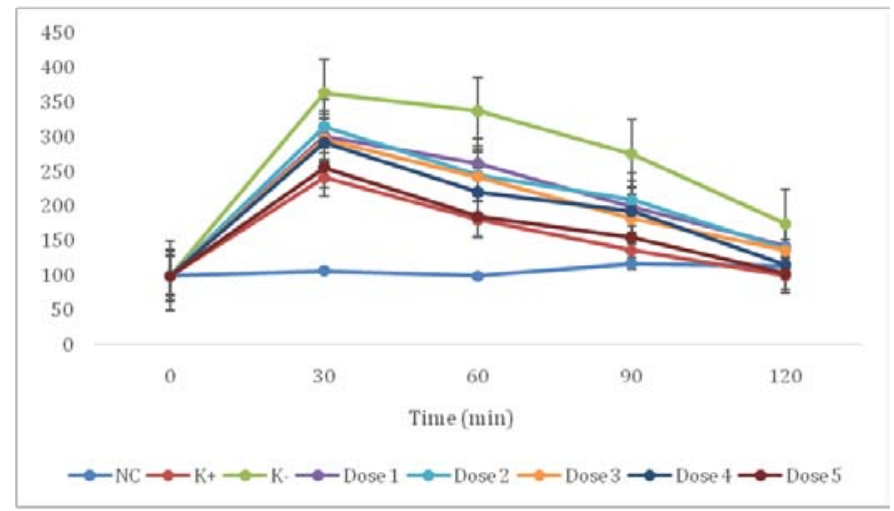

Fig. 2: Average relative blood glucose levels

Table 3: Percentage of the decrease in relative blood glucose levels

\begin{tabular}{|c|c|c|c|c|c|c|}
\hline \multirow[t]{2}{*}{ Time (min) } & \multicolumn{6}{|c|}{ Percentage of the decrease in relative blood glucose levels (\%P) } \\
\hline & $\mathrm{C}+$ & Dose 1 & Dose 2 & Dose 3 & Dose 4 & Dose 5 \\
\hline 30 & 33.63 & 17.11 & 13.17 & $\begin{array}{l}18.17 \\
\end{array}$ & 19.65 & 29.57 \\
\hline 60 & 46.30 & 22.34 & 27.25 & 27.92 & 34.68 & 44.94 \\
\hline 90 & 50.66 & 27.51 & 23.92 & 33.97 & 29.90 & 43.76 \\
\hline 120 & 42.57 & 18.36 & 20.72 & 21.87 & 33.55 & 40.55 \\
\hline
\end{tabular}

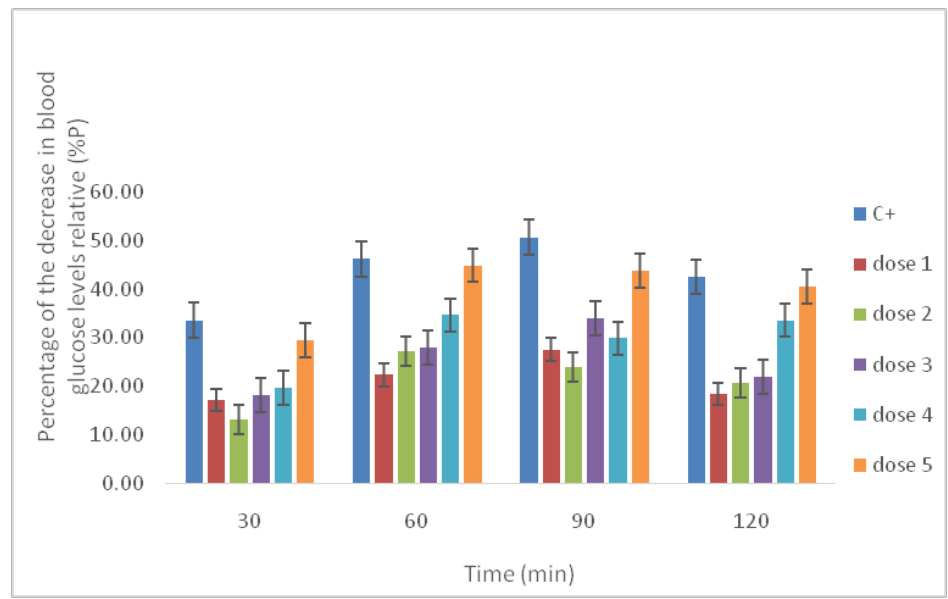

Fig. 3: Percentage of the decrease in relative blood glucose levels 
Based on the data on relatively average blood glucose levels, it is known that there was a significant difference in each dosage group in lowering blood glucose levels with Anova analysis value was $>0.05$. To find out the real difference from each group, further investigation was done using post hoc (Student Newman Keuls). The results of dose analysis of Student Newman Keuls blood glucose levels relative to each group on glucose-induced mice at each observation time can be seen in table 4 .

Table 4: The result of dose analysis of Student Newman Keuls

\begin{tabular}{lll}
\hline Treatment & N & Subset for alpha = 0.05 \\
\cline { 2 - 3 } & & $\mathbf{1}$ \\
\hline Positive control & 4 & 161.5350 \\
Dose 5 & 4 & 174.8825 \\
Dose 1 & 4 & 198.3375 \\
Dose 4 & 4 & 205.1275 \\
Dose 3 & 4 & 214.4425 \\
Dose 2 & 4 & 226.9675 \\
Negative control & & \\
Sig. & & .668 \\
\hline
\end{tabular}

\section{DISCUSSION}

Based on the results of TLC identification in fig. 1 shows that the Rf fraction value of ethyl acetate noni fruit is 0.8 , it is in line with research conducted by sadino (2018) that ethyl fraction of noni fruit acetate can reduce blood glucose levels [8]. While the results of identification of TLC cinnamon bark showed that the value of Rf 0.61 is in line with research conducted by Bayati (2009) by isolating the compound cinnamaldehyde in cinnamon [15].

The results of hypoglycemic activity test showed that the average blood glucose level relatively increased at the $30^{\text {th }}$ minute This was because mice were already in a hyperglycemic state because it is glucose-induced, but the state was only made blood glucose levels in mice increased without damaging and not causing chronic inflammation of the pancreas organs so that the mice condition is in good health. The average blood glucose level was highest in the negative group at $362 \%$, then the dose 2 , dose 1 , dose 3 , dose 4 , dose 5 group and the lowest blood glucose increase was the positive control groups. At the 0th minute, blood glucose levels were relative for all groups evenly, while the result was between the blood glucose level values on observation at the time of 0 min divided by blood glucose levels at $0 \mathrm{~min}$.

In the 60th minute, positive control had the smallest average blood glucose level with $180 \%$ then followed by dose 5 , dose 4 , dose 3 , dose 1 and dose 2 . In the $60^{\text {th }}$ minute the positive control group given glibenclamide and dose group 5 can increase the production of insulin hormone so that lower blood glucose levels have been induced glucose.

In the $90^{\text {th }}$ minute the average relative blood glucose levels of the positive control group also had the smallest value of $116.79 \%$, followed by dose 5 , dose 3 , dose 4 , dose 1 and dose 2 . In the $120^{\text {th }}$ minute there was an average decrease in relative blood glucose levels as the body returned to normal conditions or homeostasis average relative blood glucose levels.

From the results of Student Newman Keuls analysis, it can be concluded that the positive group, group 1 to group 5 has a significant difference when compared to negative control, statistically all dose groups affect the decrease in relative blood glucose levels of mice when compared to the negative control group. Flavonoid content in noni fruit is thought to lower the blood glucose levels [16]. Flavonoids are a secondary metabolite class of plants with flavon skeletons (2-phenyl chromen-4-one). Functional groups attached to the skeleton structure of basic flavonoids include flavanols, flavonols, flavon, isoflavones, flavanons, flavanols and anthocyanins. The skeleton of the subgroup has a variety of biological activities, one of which, potentially in the treatment of diabetes. Flavonoids provide activity to pancreatic $\beta$-cells and the release of insulin from pancreatic $\beta$-cells. Meanwhile, the content of cinnamaldehyde compounds in the cinnamon bark is thought to lower glucose levels in the blood. This is in line with research conducted by Guo (2017), that cinnamaldehyde significantly lowers fasting sugar level, increases insulin sensitivity and improves islet morphology and function in mice [17].
The results of the hypoglycemic activity test showed a difference in the percentage decrease in the average relative blood glucose level (\%P) of the treatment group to negative control except normal control. Based on the table above the dosage group 5 has a decrease that is almost the same as the positive control that is glibenclamide it is in line with research conducted by Jin (2007) [18] that noni fruit as hypoglycemic that can lower blood glucose levels in mice. The content of flavonoid noni fruit has therapeutic properties that can affect the digestion of carbohydrates, fat deposition and insulin release [19]. Flavonoids also have an inhibitory effect on the enzyme $\alpha$-glucosidase through hydroxylation bonds and $\beta$-ring substitution. Flavonoids are powerful inhibitors of the enzyme aamylase that function in the digestion of carbohydrates [20]. In addition to flavonoid content in noni fruit, the content of cinnamaldehyde in cinnamon bark can also lower blood glucose levels in mice [21]. In a study conducted by Anand (2010), oral administration of cinnamaldehyde ( $20 \mathrm{mg} / \mathrm{kg} \mathrm{BW}$ ) for 2 mo significantly increased the glycogen content of liver and muscle. Further in vitro incubation of pancreatic island with cinnamaldehyde (CND) has been shown to increase insulin release compared to glibenclamide. The insulinotropic effect of CND has been found to increase glucose absorption through translocation of glucose transporters (GLUT4) in peripheral tissues [22]. Thus, the combination of FEM with FEC can increase blood glucose levels in mice that are hypoglycemic.

\section{CONCLUSION}

Hypoglycemic activity test combination of ethyl acetate fraction of noni fruit and cinnamon bark on glucose-induced mice momentarily showed a decreased effect of mice blood glucose levels. Dose 5 with a dose of $175 \mathrm{mg} / \mathrm{Kg}$ BW FEM and $150 \mathrm{mg} / \mathrm{Kg}$ BW FEC provides hypoglycemic activity better compared to other dose groups with a percentage decrease in average relative blood glucose at the 30th minute of $29.57 \%, 60 \mathrm{~min}$ by $44.94 \%$, 90 th minute by $43.40 \%$ and 120 th minute by $40.55 \%$. Statistically each group made a significant difference to the decrease in blood glucose levels in glucose-induced mice when compared to the negative control group at each observation time with a $95 \%$ confidence.

\section{ACKNOWLEDGMENT}

We would like to thank Universitas Padjadjaran for supporting this research through the ALG grant in 2020.

\section{FUNDING}

Nil

\section{AUTHORS CONTRIBUTIONS}

All the authors have contributed equally.

\section{CONFLICTS OF INTERESTS}

The authors declare no conflict of interest.

\section{REFERENCES}

1. Silva JAD, Souza ECF, Echazu Boschemeier AGE, Costa CCMD, Bezerra HS, Feitosa EELC. Diagnosis of diabetes mellitus and 
living with a chronic condition: participatory study. BMC Public Health. 2018;18(1):699. doi: 10.1186/s12889-018-5637-9, PMID 29871637.

2. International Diabetes Federation (IDF). Diabetes atlas. 9th edition. International Diabetes Federation; 2019. p. 6-40.

3. Goyal R, Jialal I. Diabetes mellitus type 2. Europe; 2018.

4. Chattopadhyay RR. A comparative evaluation of some blood sugar lowering agents of plant origin. J Ethnopharmacol. 1999;67(3):367-72. doi: 10.1016/s0378-8741(99)00095-1, PMID 10617074.

5. Stein SA, Lamos EM, Davis SN. A review of the efficacy and safety of oral antidiabetic drugs. Expert Opin Drug Saf. 2013;12(2):153-75. doi: 10.1517/14740338.2013.752813, PMID 23241069.

6. Gautami J, Sree SM, dan Revathi B. Antidiabetic medicinal plant. Res Rev J Pharmacogn Phytochem. 2015;3(1):1-6.

7. Saleh B, Ata A, Kumar NVA, Sharopov F, Ramirez Alarcon K Ruiz Ortega A. Review antidiabetic potential of medicinal plants and their active components. Biomolecules. 2019;9(551):1-120.

8. Sadino A, Muhtadi A, Susilawati Y, Charisma SL. Hypoglycemic activity of ethyl acetate fraction of mengkudu fruit (Morindo citrifolia L.) in mice induced alloxan. Res J Pharm Technol. 2018;12(1):197-201. doi: 10.5958/0974-360X.2019.00036.2.

9. Lu Z, Jia Q, Wang R, Wu X, Wu Y, Huang C, Li Y. Hypoglycemic activities of A- and B-type procyanidin oligomer-rich extracts from different Cinnamon barks. Phytomedicine. 2011;18(4):298-302. doi: 10.1016/j.phymed.2010.08.008, PMID 20851586.

10. Abubakar AR, Haque M. Preparation of medicinal plants: basic extraction and fractionation procedures for experimental purposes. J Pharm Bioallied Sci. 2020;12(1):1-10. doi: 10.4103/jpbs.JPBS_175_19, PMID 32801594.

11. Ministry of Health republic Indonesia. Farmakope herbal Indonesia. Jakarta; 2017.

12. West B, Shixin D. Thin layer chromatography methods for rapid identity testing of Morinda citrifolia L. (Noni) fruit and leaf. Adv Food Sci Technol. 2010;2(5):298-302.

13. Federer W. Statistics and society: data collection and interpretation. 2nd ed. New York: Marcel Dekke; 1991.
14. Andrikopoulos S, Blair AR, Deluca N, Fam BC, Proietto J. Evaluating the glucose tolerance test in mice. Am J Physiol Endocrinol Metab. 2008;295(6):E1323-32. doi: 10.1152/ajpendo.90617.2008, PMID 18812462.

15. Al-Bayati FA, Mohammed MJ. Isolation, identification, and purification of cinnamaldehyde from cinnamomum zeylanicum bark oil. An antibacterial study. Pharm Biol. 2009;47(1):61-6. doi: $10.1080 / 13880200802430607$.

16. Fadillah RU. Antidiabetic effect of Morinda citrifolia L. As A treatment of diabetes mellitus [review]. J Majority. 2014;3(7):107-12.

17. Guo X, Sun W, Huang L, Wu L, Hou Y, Qin L, Liu T. Effect of cinnamaldehyde on glucose metabolism and vessel function. Med Sci Monit. 2017;23:3844-53. doi: 10.12659/MSM.906027. PMID 28790298.

18. Jin CB. Evaluation of hypoglycemic property of Morinda citrifolia fruit extracts in streptozotocin-induced diabetic rats. J Trap Plants. 2007;8(1):1-5.

19. Musfiroh I, Muhtadi A, Apriliani ND. Alpha-amylase inhibitory activity of extract combination of Morinda citrifolia L. Fruit, Trigonella foenum-graecum and Nigella sativa $\mathrm{L}$. seeds using in vitro and in vivo assay. Trop J Nat Prod Res. 2020;4(10):801-5. doi: 10.26538/tjnpr/v4i10.23.

20. Sasmita FW, Susetyarini E, Husamah H, Pantiwati Y. Efek ekstrak daun kembang bulan (Tithonia diversifolia) terhadap Kadar Glukosa Darah Tikus Wistar (Rattus norvegicus) yang diinduksi alloxan. Biosfera. 2017;34(1):22-31. doi: 10.20884/1.mib.2017.34.1.412.

21. Hayward NJ, McDougall GJ, Farag S, Allwood JW, Austin C, Campbell F, Horgan G, Ranawana V. Cinnamon shows antidiabetic properties that Are species-specific: effects on enzyme activity inhibition and starch digestion. Plant Foods Hum Nutr. 2019;74(4):544-52. doi: 10.1007/s11130-01900760-8, PMID 31372918

22. Anand P, Murali KY, Tandon V, Murthy PS, Chandra R. Insulinotropic effect of cinnamaldehyde on transcriptional regulation of pyruvate kinase, phosphoenolpyruvate carboxykinase, and GLUT4 translocation in experimental diabetic rats. Chem Biol Interact. 2010;186(1):72-81. doi: 10.1016/j.cbi.2010.03.044, PMID 20363216. 